The $B D J$ News section accepts items that include general news, latest research and diary events that interest our readers.

Press releases or articles may be edited, and should include a colour photograph if possible. Please direct your correspondence to the News Editor, Arveen Bajaj at the BDJ, The Macmillan Building, 4 Crinan Street, London N19XW or by email to bdj@bda.org

\section{CPD check}

The General Dental Council (GDC) is checking how much continuing professional development (CPD) dentists have completed. Dentists who first registered with the Council between 1 January 1990 and 31 December 2001 (and were on the register at 31 December 2001) should now have met the GDC's CPD requirements. These dentists have until 8 March to let the GDC know the hours they have done in 2006, and to confirm their total for the whole five-year cycle.

The Council adds that in spring 2007 it will also select a random sample of this group and seek proof of the CPD they have completed over the previous five years. If a dentist has not completed the minimum 250 hour requirement, they face being removed from the GDC's registers, losing their right to practise in the UK. After the March deadline, the Council will get in touch with any dentists this applies to and explain the urgent steps they must take to avoid losing their registration.

Dentists who first registered with the Council in other years (apart from 2006), and are part-way through a CPD cycle, have also been sent CPD annual returns which are to be returned by March. For more information contact the GDC on 020 7887 3800, email gdcregistration@ gdc-uk.org or visit the GDC website at www.gdc-uk.org/Current+registrant/ $\mathrm{CPD}+$ requirements/.

\section{Death notice}

We are sad to have to announce the deaths of Benjamin William Fickling CBE on 27 January and also of Norman Pailthorpe.

\title{
More space for dental students
}

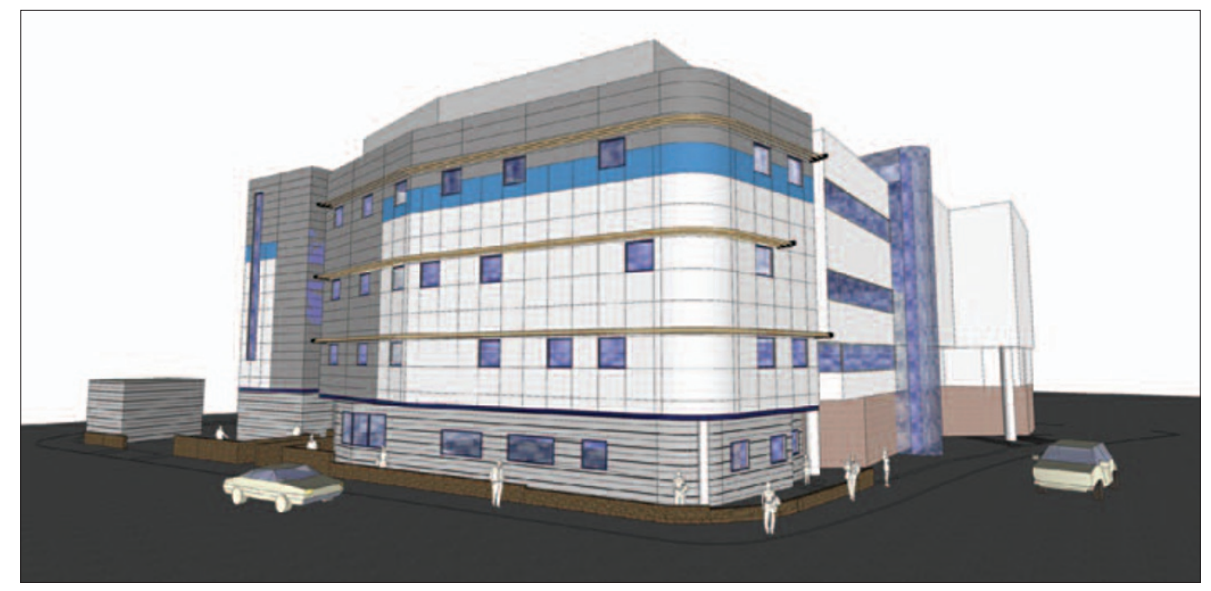

The University of Sheffield's School of Clinical Dentistry is to increase its research and teaching facilities with a $£ 5.5 \mathrm{~m}$ extension to the School. The new extension, which has received $£ 3.1 \mathrm{~m}$ of funding from the Science Research Investment Fund, is a joint collaboration between the University and the Sheffield Teaching Hospitals NHS Foundation Trust.

The four-storey extension will link with the existing School and Hospital buildings, and provide both partners with extra space for new facilities. The new wing will incorporate over $370 \mathrm{~m}^{2}$ of new research laboratory space, as well as postgraduate student offices.

The laboratories will include central resources for cell culture and tissue engineering, cell and molecular biology, proteomics, neuroscience and advanced microscopy. Building has recently started and will be completed in late 2007.

Professor Peter Robinson, who initiated the project, said, "The Dental School has an international reputation for its research work and we are delighted that we will be gaining new space and facilities. Some of the new wing is also designed to help us to accommodate an increased number of undergraduate dental students, which will help to overcome the national shortage of dentists." The design features solar controlled glazing and solar shading to minimise the energy consumption of the building.

\section{MBE for services to dentistry}

Dr Janine Brooks, Associate Director for Dentistry at the National Clinical Assessment Service, was named a Member of the Order of the British Empire in the 2007 New Year's Honours, in recognition of services to dentistry.

$\mathrm{Dr}$ Brooks worked in Community Dental Services for 20 years, having graduated from Birmingham Dental School in 1983. She has been a head of service for 17 years, first as District Dental Officer and then as Clinical Director, most recently in South Warwickshire.

Her clinical area was special needs adults and general anaesthesia. In addition she has considerable experience in general management, training, project management, confidentiality and data protection. 


\section{Genetic profiling to combat childhood dental decay}

A new method of genetic profiling may distinguish bacterial populations that cause severe dental decay in children, researchers suggest. Reporting their findings in the January 2007 issue of the Journal of Clinical Microbiology, they believe that it could be used as a basis for intervention and prevention development.

Severe early-childhood caries (S-ECC) is an extremely destructive form of bacterial tooth decay generally involving multiple teeth. Although previous studies have indicated Streptococcus mutans as a potential agent, researchers have yet to determine if S-ECC is caused by a single strain of bacteria or a group of bacterial species. Prior testing based on cultivation methods has proven difficult because nearly half of the bacteria in saliva and dental plaque are not cultivable.

In the study researchers collected plaque samples from 20 children, some with S-ECC and some caries-free (CF), and evaluated the difference in bacterial diversity using denaturing gradient gel electrophoresis (DGGE), a bial diversity and complexity of the microbial biota in dental plaque are significantly less in S-ECC children than in CF children," say the researchers. "Our study also demonstrated that PCR-based 16S rRNA gene DGGE is a sufficiently valuable tool for differentiating the microbial composition of the oral plaque in S-ECC children from that of CF children and may be further developed as a pattern recognition tool with which to identify specific groups of bacteria predominantly colonized in children of various caries status.”

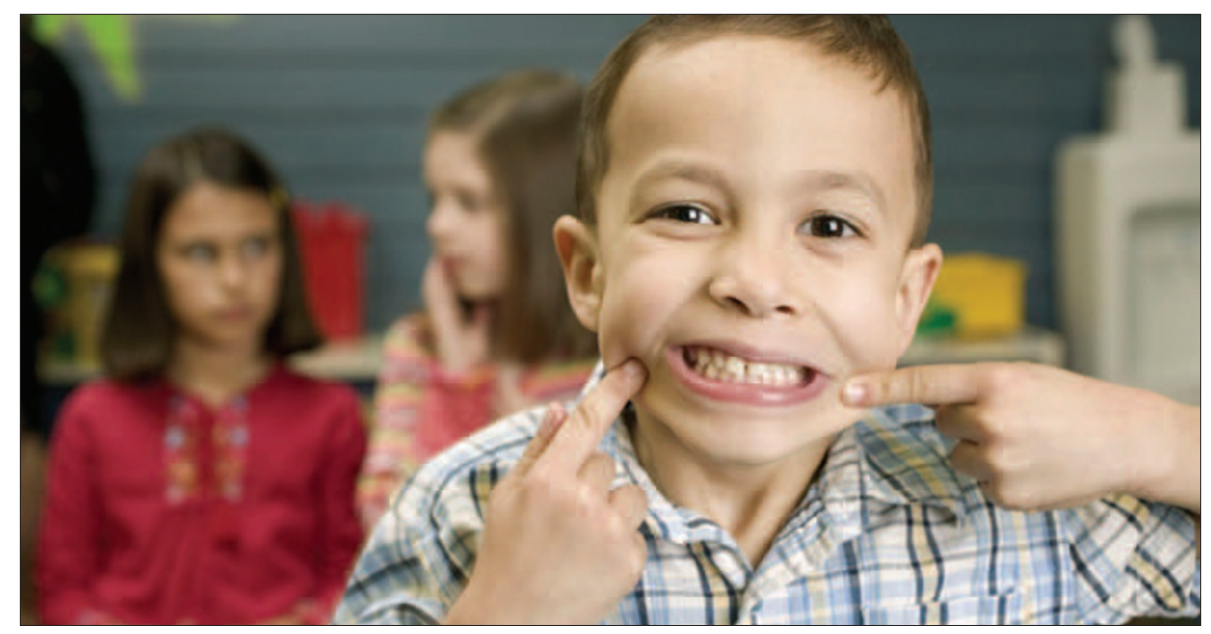




\section{Easing the pain for TMD suffers}

A new supplemental therapy that teaches pain coping and biofeedback skills can reduce pain from a common jaw disorder, University of Texas Southwestern Medical Center researchers have found. The trial evaluated early biopsychosocial intervention, which aims to help people at risk of developing chronic pain due to temporomandibular disorder, or TMD.

The UT Southwestern trial of the supplemental therapy showed patients how to self manage their pain and a combination of coping techniques and tips on controlling stress-related bodily functions. The six-week intervention teaches patients about the mind-body relationship, the body's reaction to stress and relaxation training in everyday settings. Instruction also is given on biofeedback (the use of monitoring equipment attached to the body to record changes in muscle tension, respiration and temperature) to teach a person to control those functions generally considered involuntary.

Trial participants of 20 men and 81 women who ranged in age from 18 to
70 were divided into two groups. One group got an intervention and standard dental care and the other received standard care alone.

The results, described in a study online in the Journal of the American Dental Association and in another study published in the journal's March 2006 issue, show that those who received the intervention had significantly lower levels of pain and fewer doctor visits.

While standard care for TMD, such as medication, physical therapy and surgery, can be expensive, study participants in the intervention group spent less money on treatment than those with no intervention, said Dr Anna Stowell, Assistant Professor of Psychiatry and Anesthesiology and Pain Management at UT Southwestern and co-author of the studies.

About 50 of the study participants received the intervention and a year later reported reduced levels of pain. They also displayed improved coping abilities and better moods and emotions, Dr Stowell said. The other half of the participants, who did not undergo

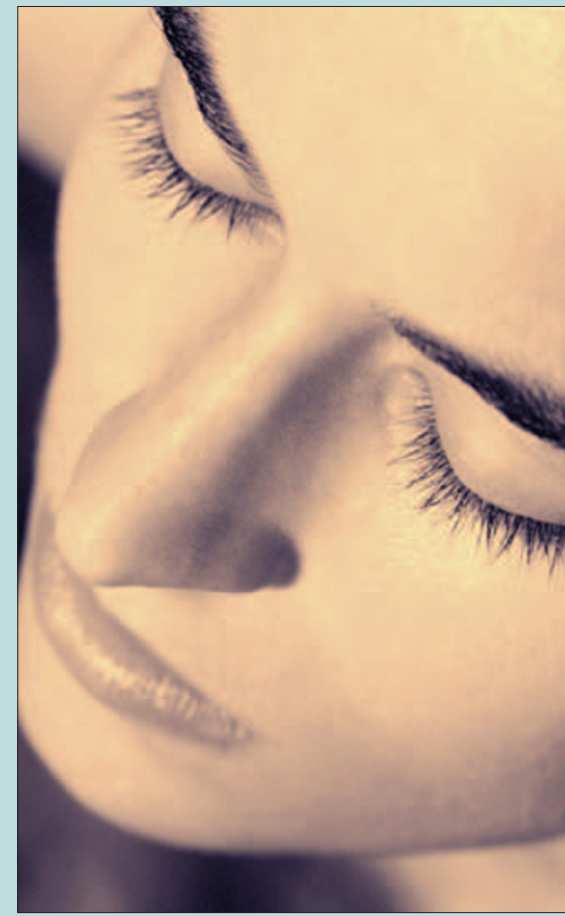

Participants were given relaxation training

intervention, made many more trips to a doctor to seek pain treatment. They also reported more general anxiety and other disorders 


\section{DIARY}

March

IAAFA Annual Conference and

Exhibition 2007

Date: 16-17 March 2007

Venue: Marriott Hotel,Regents Park, London Email:info@iaafa.net

www.iaafa.net

Healthcare Computing 2007 conference

Date: 19-21 March 2007

Venue: Harrogate

www.health-informatics.org/

April

The Society of Manchester Dental Alumni (SOMANDA) biennial meeting and reunion Date: 20 April 2007

Venue: University of Manchester

Email: carolynstylianou@ntlworld.com

The International Team for Implantology

(ITI) World Symposium 2007

Date: 26-28 April 2007

Venue: New York City

www.iti.org

May

ADI 20th Anniversary Congress

Date: 3-5 May 2007

Venue: ICC in Birmingham

www.adi.org.uk

International Osteology Symposium 2007

Date: 10-12 May 2007

Venue: Grimaldi Forum, Monaco

www.osteology-monaco.org

DSTG Annual Symposium 2007

Date: 15 May 2007

Venue: Birmingham Dental Hospital www.dstg.co.uk

\section{Smoking can cause implants to fail}

Smoking can harm the integrity of dental implants and cause them to fail more than in a non-smoker, according to a new study that appeared in the February issue of the Journal of Periodontology (JOP). Researchers from University of Murcia in Spain investigated if smoking impacts the ability of a dental implant to succeed. They found that smoking is a risk factor with regard to tooth loss and dental implant failure.

"People who smoke are at a greater risk of infection following surgery, and may heal more slowly," said Dr Arturo Sanchez Perez, Department of Periodontology at the University of Murcia.
"When an implant is placed in a smoker, it is more likely to fail. This means a patient's smile may be negatively affected, and there is potential for more bone loss in the areas surrounding the gums and teeth."

Smoking negatively affects blood flow to the bone and tissues surrounding the gums and teeth, which impairs bone healing. Implants fail because of a failure to integrate with the surrounding bone tissues. The study followed 66 patients over 5 years, who received 165 implants. They found that $15.8 \%$ of implants failed in smokers, versus $1.4 \%$ of implants in non-smokers.

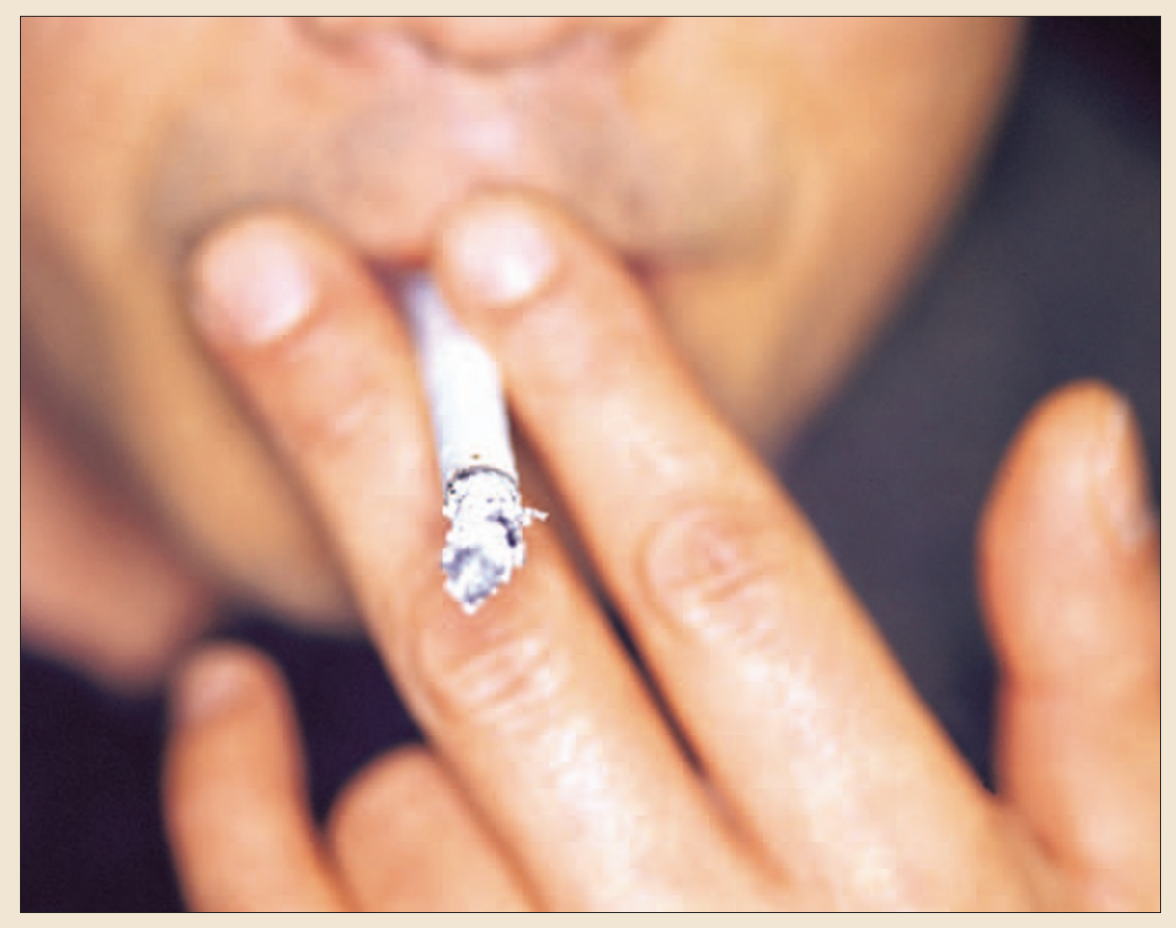

